\title{
HISTORY PERIODIZATION OF LAZAREV INSTITUTE OF ORIENTAL LANGUAGES
} (c) 2016

\author{
V.R. Avetisyan, postgraduate student of the Chair of Culturology and Arts \\ North-Caucasus Federal University, Stavropol (Russia)
}

\begin{abstract}
The problem of periodization of historical events or phenomena is always debatable. Sometimes it is difficult to find a consensus on the definition of chronological time frame of a particular event. The problem of the history periodization of Lazarev Institute of Oriental Languages is not an exception. Lazarev Institute has a rich and sometimes complicated history, so the same historical event of the institution can be interpreted in different ways. Researchers in different periods (in the pre-revolutionary period - A. Zinoviev, during the Soviet period - A.P.Baziyants, M.Nersisyan, A.T.Amirkhanyan and modern history - A.V. Torkunov, V.V. Vasilenko) developed different variants of periodization: they divided the time periods into smaller ones or united closely intertwined events into a larger period. The basic element of each periodization is a historian's principle by which he describes a historical event. The author's variant of periodization presented in the paper makes it possible to consider the problem in a new way, as it includes the chronological framework of the period preceding the beginning of teaching at the institute. This period played a significant role not only for the opening, but also in the formation of the foundations and principles of the educational institution during the time of its existence.

Keywords: periodization; education; Lazarev Institute of Oriental Languages; I.L. Lazarev; Armenian College; Moscow; St. Petersburg University; Moscow State Institute of International Relations; Russian-Armenian relations; higher education; A.V. Torkunov; debate.
\end{abstract}

УДК: $94(574.1)$

\section{АГРАРНЫЙ ВОПРОС В ЖИЗНИ ЗАПАДНО-КАЗАХСТАНСКОГО ОБЩЕСТВА В ХІХ - НАЧАЛЕ ХХ ВВ.}

(C) 2016

\author{
Д.Я. Фризен, кандидат исторических наук, \\ старший преподаватель кафедры социально-гуманитарных дисциплин \\ Актюбинский университет имени С. Баишева, Актобе (Республика Казахстан)
}

Аннотация. Аграрный вопрос был и остается актуальным для Казахстана. В данной статье с исторической точки зрения показаны особенности аграрного вопроса на рубеже XIX-XX вв., в один из самых сложных и насыщенных событиями период казахстанской истории. Переселенческая политика царизма способствовала тому, что в казахской степи стало развиваться земледелие, появились мелкие предприятия, города, хлебные рынки и т.д. Формировалась смешанная скотоводческо-земледельческая форма хозяйства, проникавшая в жизнь местного казахского населения и переселенцев. Этот вопрос довольно близко затронул ЗападноКазахстанский регион. В этих условиях происходила трансформация сельского хозяйства Западного Казахстана и вовлечение его во всероссийский рынок. Кочевники начинали расселяться вблизи русских крестьян, сеяли хлеб и зерновые культуры, в основном просо. Развитие земледелия было выгодно и в том плане, что появились хлебные рынки, что создавало для оседлого населения выгодные условия по реализации своей продукции. Как следует из материалов статьи, аграрная трансформация создавала условия для экономического взаимодействия между коренным населением и переселенцами.

Ключевые слова: Западный Казахстан; переселенческая политика; земледелие; скотоводство; трансформация; Младший жуз; Внутренняя Орда; кочевники; социальная структура; казахское общество; крестьянепереселенцы; степь; опытное поле; XIX век; XX век.

Аграрный вопрос в Казахстане всегда был в центре внимания властей, общественности, изучался учеными, общественными деятелями. Это подтверждается и в наши дни, когда попытка ввести в действие нормы нового Земельного кодекса Казахстана привели в апреле - мае 2016 года к массовым акциям протеста в ряде городов. Протесты были связаны с намерением властей отдавать землю в аренду иностранцам, что, по мнению некоторых митингующих, привело бы к тому, что казахстанский народ потерял бы землю, а затем и независимость. Все это прямо указывает на то, что аграрный вопрос чрезвычайно актуален для Казахстана, вызывает и по сей день немало споров и противоречий, представляет собой объект заботы не только властей и бизнесменов, но и рядовых граждан. В Казахстане эта тема всегда была значимой, спорной, всеохватывающей. Столыпинская аграрная реформа, коллективизация, освоение целины активно осуществлялись на территории Казахстана, вовлекая в этот процесс миллионы людей. Так или иначе, практически для каждого казахстанца вопрос о судьбе земли воспринимается как вопрос о судьбе страны. В связи с этим задача настоящей статьи заключается в том, чтобы показать значимость аграрного вопроса в Казахстане, на примере Западного региона, в исторической ретроспективе.

С древности на территории Казахстана кочевали многочисленные племена: саки, кимаки, карлуки, кыпчаки, огузы и др. В XV веке возникло Казахское ханство, занимавшее почти всю территорию современного Казахстана. В начале XVIII века ханство распалось на так называемые жузы: Старший, Сред- 
ний и Младший - и в каждом из них был свой хан. Ввиду сложного внутриполитического и внешнеполитического положения, постоянных межродовых распрей, джунгарских нашествий, набегов со стороны Хивинского ханства и других обстоятельств, казахские земли начали постепенно входить в состав Российской империи. Первым обратился с просьбой о российском подданстве к императрице Анне Иоанновне правитель Младшего жуза Абулхаир-хан в 1730 году. За ним последовали правители других жузов, но процесс вхождения казахских земель в состав России растянулся более чем на 100 лет.

В казахском обществе земля находилась в собственности того или иного рода, распоряжались земельными наделами родоначальники. Верховным распорядителем пастбищ являлся хан. Привилегированная верхушка казахского общества - султаны имели в собственности свои улусы, пастбища. В казахском обществе земля находилась в общинной собственности, принадлежала родам, жузам. Однако ввиду социального неравенства лучшие земли получали высшие социальные слои казахского общества султаны, бии, батыры, баи. Были отдельные категории населения (байгуши, консы), которые находились в зависимости от баев. Поэтому распределение пастбищ было неравномерным, с учетом социального и имущественного положения того или иного представителя кочевого общества.

С началом присоединения казахских земель к Российской империи аграрный вопрос не потерял своей остроты. Например, царизм всячески ограничивал казахским родам возможность кочевания на правом берегу Урала, Иртыша. Усилилась борьба за землю между родами. В результате обострялся земельный вопрос, начались народные восстания (например, под руководством батыра Сырыма Датова в 1783-1797 гг. в Младшем жузе). Сказывалась также нестабильность властных структур в казахской степи. Междоусобицы между султанами, ханами приводили к тому, что центральная власть значительно слабела. Этим стали пользоваться отдельные рода, которые силой захватывали пастбища у более слабых родов, отбирали скот, имущество. Участились разбои, набеги на аулы, известные в степи как барымта. Царское правительство понимало, что ханы и султаны не способны проводить политику российских властей в степи, и поэтому постепенно ханская власть была упразднена, заменена новым административным аппаратом во главе с губернаторами, назначаемыми императором. В 1868 году, согласно Временному положению по управлению в Уральской, Тургайской, Акмолинской и Семипалатинской областях, земли, принадлежащие кочевым общинам, были объявлены государственной собственностью. Это позволило впоследствии осуществлять широкомасштабные изъятия земли для предоставления их крестьянампереселенцам. В целом царизм стремился к тому, чтобы кочевники постепенно переходили к оседлости, занимались земледелием, огородничеством. Согласно статье № 125 «Степного положения», утвержденного в 1891 году, «каждый кочевник имеет право на участок, отведенный в его пользование для зимового стойбища, обрабатывать землю, разводить сады, огороды и рощи и возводить жилые и хозяй- ственные постройки» [1, с. 108]. Возведение жилых построек способствовало процессу оседания кочевого и полукочевого населения, поскольку возведение постоянных жилищ привязывало кочевников к определенной местности.

Помимо законодательной базы царское правительство предпринимало также меры по экономическому стимулированию перехода кочевников к оседлости. Для этого им стали выделяться земельные участки, ссуды на строительство жилья и т.д. Царский режим также ввел новые формы разрешения земельных тяжб между казахами. В более ранние времена в казахском обществе земельные тяжбы разрешались биями, т.е. судьями, родоначальниками, а также ханами. Постепенно российская администрация взяла этот вопрос под свой контроль. Съезды по разбору земельных споров и тяжб стали собираться с разрешения губернатора. Председателем съезда был уездный начальник, который отчитывался перед губернатором. Полномочия родоначальников, биев в этих вопросах постепенно сошли на нет. С созданием уездных и областных судов вопросы земельных отношений постепенно стали рассматриваться в судебном порядке.

Чтобы усилить свое политическое и экономическое влияние в казахской степи, самодержавие стремилось заручиться поддержкой влиятельных казахских семей, чтобы через них управлять этим народом. Например, несмотря на запрет казахским родам кочевать на правом берегу Урала, были сделаны послабления для казахской правящей элиты. Хану Нуралы (1748-1786) и его ближайшему окружению было разрешено в зимнее время перекочевывать на правый берег Урала, что, однако, не касалось рядовых кочевников. В дальнейшем подобные послабления в перекочевках касались родовой верхушки казахского общества.

Западный Казахстан занимал огромную территорию, и многие земли не были приспособлены для земледелия. Например, на Мангышлаке традиционно развивалось скотоводство, а земледелие было развито слабо. 13 августа 1847 года было принято решение о заселении Мангышлакского полуострова вблизи Тюз-тюбинского залива. В 1846 году на Мангышлаке было основано Ново-Петровское укрепление. Переселенцы в этом регионе бесплатно получали земельные участки. Царские власти стремились укрепить свое влияние также и в тех районах, где земледелие не развивалось ввиду специфических природноклиматических условий. Активно создавались новые органы власти, которые должны были усилить роль царской администрации в деле управления кочевниками. В отчете Уральского военного губернатора отмечалось: «Наиболее важный вопрос, от которого зависит дальнейшее развитие всех сторон общественной гражданской линии, оседлого и кочевого населения Уральской области, заключается в том, какое окончательное решение последует по проекту изменений во Временном положении относительно будущего устройства административных и судебных учреждений области» [2].

Царизм занял довольно принципиальную позицию в отношении земли, находившейся в собственности кочевых общин, объявив их государственной 
собственностью: «По 4 параграфу Высочайше утвержденного в 14 день июня 1844 года Положения об управлении Оренбургскими киргизами, земли в области составляют собственность государственную и предоставлены киргизам в общее пользование. При кочевой жизни киргизов раздел участков совершается самими обществами, а областной начальство наблюдает только, чтобы каждый пользовался землей сообразно действительной необходимости и чтобы сильные и богатые не обижали слабых и малоимущих» [3]. Даже при условии того, что тот или иной кочевник хотел заниматься земледелием, надел ему предоставлялся лишь в пользование. В отчете Оренбургской пограничной комиссии отмечалось: «С усилением в последнее время между киргизами хлебопашества, что им прежде воспрещалось, и для развития в Ордынском населении гражданственности по представлению бывшего Оренбургского и Самарского генерал-губернатора, генерал-адъютанта Катенина, последовало Высочайшее разрешение на дозволение киргизам строить дома и заниматься земледелием на отводимых им участках в пользование, но не в собственность» [3, л. 5].

Царское правительство понимало, что с увеличением темпов оседания кочевников, развития земледелия, создания оседлых поселений будет возрастать экономическое влияние России в казахском крае. Поэтому стали появляться так называемые «опытные» поля, где выращивались сельхозкультуры, открывались ссудные кассы, выделялись участки под оседлые поселения, в том числе и для казахов и т.д. Одной из подобных экспериментальных площадок было Темирское опытное поле в Уральской области. Рост числа крестьян-переселенцев из центральной России, украинских, белорусских губерний способствовал тому, что изменялся национальный состав края, увеличивалась доля земледелия по сравнению со скотоводством. Казахстан активнее стал включаться во всероссийский рынок, появились города, железные дороги, школы, больницы, различные госучреждения и т.д. Но, по-прежнему, аграрный вопрос был наиболее актуальным для казахского народа, а также и для переселенцев.

В 1801 году по указу императора Павла I на территории между Уралом и Волгой было образовано Букеевское ханство, более известное в источниках как Букеевская (Внутренняя) Орда. Вместе с султаном, а с 1812 года с ханом Букеем переселились на новые земли некоторые роды Младшего жуза. По словам Б. Аспандиярова, «первые букеевцы поселились на побережье Каспийского моря. Как зимние пастбищные угодья побережье моря было очень удобным для кочевого хозяйства, оно служило хорошим укрытием. В камышовых зарослях и люди, и скот находили себе хорошую защиту от зимней стужи и вьюг, корм и топливо. Для питьевой воды пользовались снегом. Зимой пасти скот в открытых степных местах не всегда было возможно. Побережьем моря казахи пользовались только в зимнее время, а летом откочевывали от берега, так как летом, вследствие недостатка пресной воды, а также множества оводов, здесь очень трудно было жить и пасти скот. Часть их кочевала в Нарын-песках, а часть уходила за Урал, и осенью возвращались на свои места» [4, с. 62].
Однако вскоре на территории Букеевской орды сложилась довольно сложная ситуация с распределением пастбищ. Хан и его приближенные стремились присвоить себе лучшие пастбища, наиболее удобные для кочевания. В итоге участились народные волнения против произвола ханских чиновников и захвата земель. «Земли, отведенные под общее пользование, - писал С.3. Зиманов, - настолько были малы или неудобны, что ни в коей степени не могли удовлетворить потребности кочующих там коллективов. Преобладающее число аулов, уходя из одного владения, попадали в пределы владений другого собственника и в конце концов оказались вынужденными платить определенную подать, арендную сумму владельцу угодий за пользование и кочевание на их землях» [5, с. 361]. Самым крупным восстанием в истории Букеевской орды было народно-освободительное движение под руководством Исатая Тайманова и Махамбета Утемисова в 1836-1838 гг. Главным требованием восставших было смещение Жангир-хана (преемника Букей-хана) и возвращение народу изъятых земель. Аграрный вопрос был наиболее проблемным в ходе восстания. Не случайно отряды восставших начали отбирать пастбища и скот у биев и султанов. Аулы ряда ханских приближенных были разграблены. Восстание удалось подавить лишь после прибытия карательной военной экспедиции из Оренбурга.

Аграрный вопрос стоял на повестке дня и в период переселенческой политики царизма, поскольку возник вопрос о наделении землей вновь прибывающих переселенцев. Для определения размеров земельных угодий в Казахстане по приказу правительства работали несколько земельных комиссий, одной из которых была экспедиция по исследованию степных областей под руководством Ф.А. Щербины. Было выделено несколько десятков миллионов земли под видом «излишков», что создавало почву для их изъятия в переселенческий фонд. В действительности эти земли ранее принадлежали кочевым общинам, которые здесь кочевали круглый год. Кочевники не задерживались долго на одном месте и переходили на новые пастбища. Комиссии приходили к выводу, что данные территории не использовались в полной мере, и определяли их как «излишки». Здесь сказывалось также непонимание специфики кочевого скотоводства, что приводило к изъятию пастбищ. Ввиду этого росло недовольство казахского населения земельной политикой царизма, вылившееся в народное восстание в 1916 году. Одной из главных причин данного восстания было обострение земельного вопроса.

Несмотря на развитие земледелия, скотоводство также не теряло своих позиций в системе хозяйства Западного Казахстана. Это было обусловлено во многом тем, что постепенно росли цены на мясо и продукцию животноводства. Понимая значимость развития мясного скотоводства, царские власти стремились развивать на территории Казахстана помимо коневодства, овцеводства также и разведение крупного рогатого скота, свиноводство. Однако овцеводство и коневодство развивались наиболее сбалансированно, в особенности в казахских хозяйствах. С.Н. Фустов отмечал: «Правительство, желая содействовать улучшению местной породы лошадей, раз- 
давало бесплатно заводских жеребцов в табуны богатых киргиз и, чтобы поощрить развитие лошадей породистых, учредило при ставке с пятью призами от 120 до 15 рублей» [6].

Для урегулирования земельных споров между казахскими родами, царское правительство стало привлекать на службу казахов, хорошо знающих особенности хозяйства и быт местного населения. Например, начальник Оренбургской пограничной комиссии докладывал Оренбургскому генерал-губернатору: «Между кочующими в 28 дистанции по реке ЯхмиКаргале киргизами жагалбайлинского рода возникли недовольства и споры из-за поземельных угодий... Вследствие сего, согласно отзыву Управляющего, областное правление, предписав чиновнику для контроля в степи, подпоручику султану Сейдалину отправиться в 28 дистанцию на места, из-за которых идет помянутый спор, и удостоверившись, на чьей стороне справедливость, доставить обиженным удовлетворение безобидным переделом земли. При этом Правление долгом считает доложить Вашему Превосходительству, что... признав помянутую командировку султана Сейдалина, считаем весьма удобной для того, чтобы по окончании оной поручить ему собрание различных данных, необходимых для разрешения предложенных правлению от генералгубернатора задач, предписав Сейдалину заняться еще и означенным предметом и потом предоставить к нему, как наблюдения, которые он сделает, так и собственные соображения» [7]. Ряд представителей казахского общества привлекались на российскую службу, в основном в структуру колониальной администрации. Известными казахами, находившимися на российской службе, были Чокан Валиханов, Ибрай Алтынсарин, Алихан Букейханов, Халел Досмухамедов и др.

Царское правительство на первом этапе стремилось проводить колонизацию казахской степи постепенно, заселяя эту территорию крестьянамипереселенцами и не нарушая традиционные маршруты кочевания. Оренбургский генерал-губернатор в своем письме уездным начальникам от 29 сентября 1889 года отметил: «... внутренний быт киргизов сохраняется на основании народных обычаев, и как перекочевание составляет одну из самых существенных сторон народного быта киргизов и их обычаев, то очевидно, что прежнее право перекочевания сохраняется» [7, л. 18 об.]. Под воздействием переселенческой политики казахские хозяйства стали больше ориентироваться на развитие не только скотоводства, но и земледелия. В конце XIX века в Букеевской Орде было 46002 хозяйств, в которых находилось 12\% лошадей; 19,7\% крупного рогатого скота; 6,3\% верблюдов; $52,7 \%$ овец; 9,3\% коз. В Гурьевском уезде насчитывалось 22784 хозяйств, в которых было 7,7\% лошадей; 8,6\% коров; 11,5\% верблюдов; 69,2\% овец; $3 \%$ коз. Мангышлакский уезд включал 14961 хозяйств. В них 4,6\% лошадей; $0,1 \%$ коров; 4\% верблюдов; 84,6\% овец; 6,7\% коз. В Актюбинском уезде насчитывалось 17837 хозяйств. Лошади составляли $13,9 \%$; коровы 29,2\%; верблюды $1,7 \%$, овцы 44,5\%, козы $10,7 \%$ [8, с. 94-95]. Постепенно возрастали темпы земледелия. По сведениям Мухаммед Галия Тяукина, «киргизы сеют: пшеницу, овес, просо. Сверх означенного употребления, для сохранения здоровья
07.00.00 - исторические науки и археология

баранов... мотыгой зимой расчищают снег и твердую поверхность земли, на которую во время ночи ложатся бараны» [9, с. 324]. В Тургайском уезде процент сеющих хозяйств составлял в конце XIX века 23,3\%, в Актюбинском уезде - 96\%, в Кустанайском уезде $88,5 \%$, в Уральском уезде - 85,1\%, в Лбищенском уезде - $35,5 \%$, в Темирском уезде - $77,9 \%$ [8, с. $168-$ 169]. То есть процент сеющих хозяйств был довольно значительным, особенно в Актюбинском и Кустанайском уездах.

Заселение и экономическое развитие Западного Казахстана осложнялось также в связи с тем, что в данном регионе была не развита сеть дорог, населенные пункты находились далеко друг от друга. А.И. Добросмыслов так описывал дороги в Тургайской области: «В северных уездах области - Актюбинском и Кустанайском - летом так много дорог и так они между собой переплетаются, пересекаются и перепутываются, что добраться по ним до намеченного пункта почти невозможно, не изучив эту сеть основательным образом и не побывав в одном и том же месте несколько раз в разное время года. Большинство дорог, с едва примятой травой, летом мало заметны, а зимой, заметенные снегом, трудно различимы даже днем» [10, с. 1-2]. Тем не менее, процесс аграрной трансформации в регионе набирал темпы.

Таким образом, аграрный вопрос в Западном Казахстане был достаточно актуальным в социальнополитическом и экономическом развитии региона. Вопрос о землеустройстве стоял на повестке дня практически постоянно, на протяжении всего изучаемого периода. Переселенческая политика царизма ускорила переход кочевого населения к оседлости, и все более актуальным становился вопрос о развитии хлебопашества, освоения для этих нужд новых земель. Западный Казахстан активнее начал включаться во всероссийский рынок.

\section{СПИСОК ЛИТЕРАТУРЫ:}

1. Крафт И.И. Сборник узаконений о киргизах степных областей. Оренбург: Типография П. Жаринова, 1898. 532 с.

2. Государственный архив Оренбургской области (ГАОО). Ф. 6. Оп. 17. Д. 219. Л. 14.

3. ГАОО. Ф. 6. ОП. 17. Д. 79. Л. 3.

4. Аспандияров Б. Образование Букеевской Орды и её ликвидация. Алматы: Казак энциклопедиясы, 2007. $400 \mathrm{c}$.

5. Зиманов С.3. Политический строй Казахстана первой половины XIX века и Букеевское ханство. Алматы: Арыс, 2009. 496 с.

6. Фустов С.Н. Заметки о торговле Внутренней Киргизской Орды // Оренбургские губернские ведомости, 1868. № 16. С. 73.

7. ГАОО. Ф. 6. Оп. 10. Д. 8112 . Л. 9.

8. Хозяйство казахов на рубеже XIX-XX веков: Материалы к историко-этнографическому атласу. Алма-Ата, 1980. 256 с.

9. Записка Мухамед-Галия Тяукина о хозяйстве ордынцев // Экономические записки. 1861. № 41. С. 324-325.

10. Добросмыслов А.И. Транзитное передвижение промышленного скота и животных продуктов через Тургайскую область с 1891 по 1895 гг. Оренбург, $1896.46 \mathrm{c}$. 


\title{
THE AGRARIAN QUESTION IN LIFE OF WESTERN KAZAKHSTAN SOCIETY IN THE 19 - EARLY 20 CENTURIES
}

\section{(C) 2016}

D.Y. Frizen, candidate of historical sciences, senior lecturer of the Chair of Social and Humanitarian Disciplines Baishev University Aqtobe, Aktobe (Republic of Kazakhstan)

\begin{abstract}
The agrarian question is a very urgent problem in Kazakhstan. The following paper shows the history of struggle for land in 19-20 centuries. At those times Kazakhs were nomads. Tsarism carried some reforms and made the lands in the Kazakh steppe the property of the state. In Western Kazakhstan agriculture, cattle breeding, trade developed. In the Kazakh steppe agrarian transformation started. Nomads started to build permanent dwellings. These buildings were near the Russian peasants. Construction of railways led to the fact that the Kazakhs and Russian peasants sold bread at the markets near stations. Stolypin agrarian reform accelerated the process of agrarian transformation. Eventually, Western Kazakhstan entered into Russian market.

Keywords: Western Kazakhstan; resettlement policy; agriculture; cattle breeding; transformation; the Younger zhuz; Inner Horde; Nomads; the social structure; the Kazakh society; peasant settlers; steppe; experimental field; XIX century; XX century.
\end{abstract}

УДК 94(47):327

\section{ДЕЯТЕЛЬНОСТЬ Н.В. ЧАРЫКОВА ПО РЕФОРМИРОВАНИЮ МИНИСТЕРСТВА ИНОСТРАННЫХ ДЕЛ РОССИИ} (C) 2016

О.А. Чернов, кандидат исторических наук, доцент кафедры отечественной истории и археологии Самарский государственный сочиально-педагогический университет, Самара (Россия)

\begin{abstract}
Аннотация. Проблема реформирования министерства иностранных дел Российской империи в начале XX века нашла освещение в исторической литературе. Однако роль Н.В. Чарыкова освещена весьма кратко. Поскольку он был председателем Совещания по реформированию министерства иностранных дел, представляется необходимым изучить его идеи и роль в данном преобразовательном направлении. Руководителем Совещания по реформированию центральных учреждений министерства иностранных дел он стал после того, как получил назначение на должность товарища министра иностранных дел. Это, в свою очередь, произошло после того, как министром иностранных дел стал А.П. Извольский - друг и однокурсник Н.В. Чарыкова по Александровскому Императорскому лицею. Н.В. Чарыков указывает, что А.П. Извольский пригласил его стать заместителем министра иностранных дел. Все юридические дела министерства иностранных дел были переданы А.П. Извольским в полное распоряжение Н.В. Чарыкову.

Н.В. Чарыков занимал должность товарища министра иностранных дел и возглавлял Совещание по реформе министерства иностранных дел, осуществляя вдумчивую и кропотливую работу. Он сумел наладить координацию действий всех ведомств, от которых зависело реформирование. Также он полагал необходимым изменение структуры министерства иностранных дел, увязывая её с необходимостью увеличения финансирования. Кроме того, выступал за расширение дипломатической переписки на русском языке. Важным моментом была мысль о необходимости демократизации дипломатического экзамена, с одной стороны, и одновременно повышении уровня образовательных требований к кандидатам - с другой.

Ключевые слова: Н.В. Чарыков; А.П. Извольский; М.А. Таубе; .Н. Губастов; .Н. Михайловский; И.А. Персиани; С.М. Горяинов; А.А. Нератов; В.О. фон Клемм; Г.А. Плансон; М.И. Муромцев; Ю.Я. Соловьев; К.К. Буксгевден; А.К. Бентковский; Александровский лицей; реформа; министерство иностранных дел; внешняя политика России; российская дипломатия.
\end{abstract}

Николай Валерьевич Чарыков - заметный государственный деятель Российской империи начала XX века [1;2] - принял непосредственное участие в преобразовании министерства иностранных дел России.

После того как МИД России возглавил А.П. Извольский, началось его реформирование. Под его руководством был разработан проект «коренной реформы МИД» [3, с. 85]. Е.Г. Кострикова указывает, что данная проблема назрела к началу XX века и многие дипломаты высказывали свои предложения в этом направлении. Решающим фактором стало назначение министром иностранных дел А.П. Извольского, который «без промедления приступил к подготовке общей реформы министерства» [4]. Как от- мечает В.Е. Авдеев, «одним из приоритетов деятельности А.П. Извольского на посту министра иностранных дел являлось решение проблемы реформы дипломатического ведомства, без которой модернизация всего механизма государственного руководства внешней политикой была лишена смысла» [5, с. 109; 6]. Российский внешнеполитический механизм получил подробное освещение в работах В.А. Емеца [7; 8], разбирались его аспекты в трудах А.В. Игнатьева $[9 ; 10]$.

Таким образом, проблема реформирования МИД России в начале XX века нашла освещение в исторической литературе. Однако роль Н.В. Чарыкова освещена кратко. Поскольку именно он был руководителем Совещания по реформированию централь- 